\title{
EVALUATION OF URBAN ESTHETICS FROM THE ASPECT OF TOURISM: THE BOSNIA-HERZEGOVINA EXAMPLE
}

\author{
Tülay Polat Üzümcü ${ }^{1}$ \\ Aysun Çelik ${ }^{2}$ \\ Emrah Özkul ${ }^{3}$ \\ Ersin Uğurkan ${ }^{4}$
}

\begin{abstract}
Summary: Cities are dynamic phenomena containing natural, cultural, historical, social and artificial elements including people, and shaped by requirements of daily life. Such elements comprising cities are elements also constituting source for tourism. From the point of tourism, the main component of urban environment is view quality and areas with a high quality of view are also areas which are attractive for touristic activities. Sustainable tourism which is an important industry for economic development purposes is closely related to modernization of cities without impairing their natural or cultural texture and prevention of impairment of urban esthetics which is one of the fundamental attraction elements of tourism. In this study natural and cultural resources shaping the environment and constituting resource for tourism in Bosnia-Herzegovina has been esthetically evaluated and visual tastes have been identified and urban esthetics has been emphasized in terms of tourism. For this purpose, various literature data has been analyzed in the study and experiences and data obtained by direct observation have been evaluated to identify tourism facilities in BosniaHerzegovina.
\end{abstract}

Keywords: Urban esthetics, Tourism, Bosnia-Herzegovina

\section{INTRODUCTION}

Cities are formed by combination of natural and cultural elements. Being a complement of systems, cities are highly complex areas which are very difficult or impossible to control and have cultural diversity and incorporate natural and artificial elements. Factors which directly determine urban formation and urban macro form include social values, sociocultural structure, life form, technology, population structure, economy, transport textures and urban policies (Erdoğan, 2006). Besides serving to a certain purpose, for cities to have an urban image, they must incorporate feeling-arousing esthetic values. Therefore, human beings have sought for esthetic qualities in urban environments during the history and tried to bring an order to their environment.

Environment covers each, part or all of natural and artificial physical structure, climatic and geographical assets, biological factors, and cultural, social, economic and artistic formations (İzgi, 1999). Natural, cultural, historical, esthetical and visual elements and properties comprising urban environment also constitute a resource for tourism. They have a significant role historically for protection of beautiful views and places which are considered to be a "rare beauty" Fuante de Val et al., 2006; Daniel, 2001). Main component of natural environment in tourism or recreational context is visual or view quality. Important landscapes in terms of view are not only beneficial to individuals living there but they also make a significant contribution to attractiveness of the area; therefore

\footnotetext{
${ }^{1}$ Ass Prof. Dr., Kocaeli University, Turkey.

${ }^{2}$ Asoc..Dr., Uludağ University, Turkey.

${ }^{3}$ Asoc..Dr., Kocaeli University, Turkey.

${ }^{4}$ Lecturer., Kocaeli University, Turkey.
} 
they can be associated with economic benefits of the area. Because visual characteristics affect the entire quality of a touristic/recreational experience (Clay and Daniel, 2000).

Unplanned urbanization resulting from rapid population growth and migration leads to siege of cities, harm to core texture, impairment to urban esthetics, and destruction of historical, cultural and natural assets which are core elements of tourism. Tourism which is an effective tool to protect and improve environmental elements is an important industry contributing to economic, social and cultural development processes of countries at national and international level (Kuter, 2007). Being an important industry for economic development, sustainable tourism is closely related to modernization of cities without impairing their natural and cultural texture and impairment of urban esthetics which is one of fundamental attraction elements for tourism.

Esthetical and environmental arrangements affect purchasing decisions of consumers (cars, clothes, meal service in a restaurant, travel etc.) (Oral and Çelik, 2013, 173). Even though there are sustainable tourism types protecting the environment today, tourism also has certain aspects having negative effects on the environment, harming also itself and leading to rapid/unplanned urbanization. Rapid and unplanned urbanization, irregular facilities built with commercial considerations, deviation from natural and local texture, negative effects caused by mass tourism, environmental pollution, damage to cultural heritage, corruption of local culture and consequently impairment of urban esthetics have also negative effects on sustainable tourism.

This study focuses on the tourism in Bosnia-Herzegovina which is defined as Jerusalem of Europe by many famous writers. The study attempts to provide esthetical evaluation and visual taste of natural and cultural resources forming the environment and constituting a resource for tourism in Bosnia-Herzegovina. For this purpose, literature review has been conducted on the field primarily to describe significance of urban esthetics in terms of tourism. It has been then attempted to identify cultural, historical and natural assets of the research area using data obtained from examination of studies showing historical and spatial development process of the research area - photos, videos etc.), and thesis, research, article, book and internet data etc. related to the research area. The theoretical framework formed by data obtained is intended to demonstrate the effects of general characteristics, urban esthetics and tourism potential of Sarajevo on improvement of tourism. In this scope, some suggestions have been made to ensure sustainability of tourism facilities and urban esthetics which the city has. Tourism in Bosnia-Herzegovina is open to growth and it is a destination that will make contribution to economic development of the local people with tourism investments and aids. Urban esthetics is very important for tourism and sustainable tourism approach requires ensuring urban esthetics and creating tourism economy.

\section{CONCEPTUAL FRAMEWORK}

The word "esthetic" is rooted from the Greek words "aisthesis" or "aishanesthai". It has various meanings such as sensation, senses, perception, and perceiving with feelings. Esthetics is the science of information provided by feelings. As specified in the study by Ergün (2005), the first philosopher who carried out a systematic research on what the "beautiful" is from the view of existence and knowledge is Plato while Baumgarten is the first philosopher who used the concept of esthetics rooting from the Greek word "aesthesis" (perception, sensation) as an independent discipline. According to him, esthetic is the "science of thinking on beautiful". Esthetics is theories on how something arouses 
the sense of beautiful in people (Çakc1, 2007). Esthetics does not only cover the beautiful in art, i.e. the philosophy of art, but also the beautiful in nature. Thus, it is the discipline of perceptions, the science of senses used for evaluation of both natural and artificial elements (Bozkurt, 2000). Esthetical experience means symmetry, proportion, harmony of objects, concordance or performance. In consumption, esthetics is evaluated based on the ability of visual element or service performance to arouse feelings (Oral and Çelik, 2013, 173). If culture and art are the most significant comments representing and telling people to people, esthetics is one of the main areas of interest which cities that that incorporate all technical and poetical aspects of both art and culture and is a historical product of human beings should have (Erzen, 2011).

Esthetics means sensation/the sensed/perceiving with feelings, and thus comprehending the beautiful and achieving the sense of pleasure. According to another definition of esthetics, it is the art of thinking on the beautiful and researching what the beautiful is. The branch of philosophy focusing on the beauties which look nice or give pleasure to us and arouse feelings or enthusiasm in us, in other words examining nature of the beautiful and fine arts is called esthetics (www.egitim.aku.edu.tr). In this sense, tourism is intertwined with esthetics. The reason for this is, unlike other industries, when we mention of tourism, it reminds us of elements such as spatial beauty, historical structures or environmental beauty, and their harmony, which awakes a sense of delightfulness, pleasure and grace in people. Urban esthetics is a phenomenon which is primarily related to life of people in city and their mental and social status (Erzen, 2011). The most important factor comprising urban esthetics throughout the history has been natural environment. It is seen that elements such as geomorphology, topography, vegetation, climate and availability of water which are components of natural environment have a significant role in both selection of places where cities are founded and formation of cities. Cities which are in harmony with these elements have a greater level of esthetical values. Cities which are well integrated with its surroundings in terms of materials as well as structuring and natural elements have more qualified surroundings. As in urban structuring, urban esthetics is a phenomenon directly related to social, cultural, technological and economic structure of the period when it is produced (Elmas, 2006).

Urban environments consist of positive and negative elements. Defined relationships between them, liquid space, well-designed spatial transitions and harmony determine the quality of urban esthetics (Erdoğan, Elmas, 2006). Values of cities arise from multiple properties and various cultural dimensions. Two important factors which gives the city quality to a city are the feeling that we reach back and ahead over time, we can create expectations in it, and we feel rooted by feeling past lives in a way. This property of cities means that physical structure of a city makes us feel and perceive the past time and historical process, and new constructions and practical applications direct us to the future (Erzen, 2011). In this case, the greater the integrity of an urban environment is and the more ordered it is, the greater its esthetical value is. Esthetically evaluating order and regularity of tourism facilities, the extent to which historical places can be protected, sociopsychological attitude towards tourists adopted by societies with tourism potential, and pleasure felt by visitors, esthetical deficiency in them also creates a situation working against tourism. Direct proportion between tourism and esthetics shows actual operability of tourism and what is required. When Esthetics and Tourism are associated, it is seen that tourism exists where there is esthetics. 


\section{GENERAL PROPERTIES OF BOSNIA-HERZEGOVINA}

\section{a) Natural Properties}

Bosnia-Herzegovina is seated at the southeast of the continental Europe and the northwest corner of the Balkan Peninsula. It reaches to the Adriatic Sea with a $20 \mathrm{~km}$ piece of land where River Neretva falls into the sea, but it does not have a port. It is surrounded by Croatia in the north and the west, Serbia in the east, and Montenegro in the southeast. Sarajevo, capital of Bosnia-Herzegovina has a surface area of $51.129 \mathrm{~km} 2$ and a population of 4.523.000 people and its official language is Serbian, Croatian and Bosnian and its religion is Islam (http://www.cografya.gen.tr/siyasi/devletler/bosna-hersek.htm). Sarajevo is the capital of the country and the city which is the center is the most important city of Bosnia-Herzegovina. Big cities of the country which are local centers include Tuzla, Banja Luka, Mostar, Bihac, Doboj, Bugjyno, Travnik, Zenica, Livno, Trebinje ve Gorajde, Prijedor, Derventa, Brcko, Bijeljina, Zvornik, Jajce, Visoko, Visegrad, Foca and Konjic, and its most important center is Mostar which looks like an Ottoman city (Kondo, 2003, 84).

The State of Bosnia-Herzegovina consists of two individual areas including Bosnia and Herzegovina. Bosna is the north of the country containing the cities Srajevo, Travnik and Tuzla etc. while Herzegovina is the area closer to Dalmatia and Adriatic, containing the cities Mostar and Konjic etc. Bosnia is populated mostly by Bosnians and Serbians while it is seen that Herzegovina is predominantly populated by Bosians and Croatians. The areas Bosnia and Herzegovina have different physical properties. Bosnia is a terrestrial area with a mountainous and forestland nature and a cold climate and summers are hot while winters are snowy and cold. Herzegovina which is a smaller area in the south coasts of the country has a Mediterranean climate. This area has a warm climatic environment and maquis-like vegetation. Rivers Sava and Drina pass through Bosnia while River Neretva passes through Herzegovina. Bosnia has dense and luxuriant forests while Herzegovina consists of deep canyons comprised of white rocks due to existence of limestone (Özder, 2012, 219-221).

A small part of the Adriatic Sea belongs to Bosnia-Herzegovina and its coast consists of Klek Peninsula of $24 \mathrm{~km}$ length and Neum Gulf. The city of Neum seated more southwards from Neretva Delta is the only city with a coast on the sea in BosniaHerzegovina. River Neum which is the only outlet in the sea in Bosnia-Herzegovina is the most important touristic area of the country. All underground and surface waters in the country have a big significance both for the industry and the economy of BosniaHerzegovina. Most of the streams here have a great potential for hydroelectric power generation. Besides importance of the waters for economy and industry of the country, their importance for touristic purposes should also be noted. Especially the sea and hot water resources in Fojnisa, Olovo and Teslic have great importance for tourism in the country. Main streams of Bosnia-Herzegovina include Sava, Una, Vrbas, Bosnia, Drina, Neretva and Trebisnjisa (Kondo, 40/46).

\section{b) Historical and Cultural Properties}

Population of Bosnia-Herzegovina is dense in the north and northeast parts of the country while the west and the southeast parts are less populated. As the result of rapid increase in urban population due to a major part of the population leaving the agricultural industry and having job opportunities in other industries and acceleration of urbanization, it has resulted in population growth in certain areas of the country (Kondo, 2003, 63). BosniaHerzegovina lost its economic power by 90\% during the civil war between the years 1992 
and 95 and over 2 million people living in the country were displaced. The country whose economy is majorly dependent on foreign aids and loans has an unemployment rate of about $40 \%$ and where $60 \%$ of the young population wants to move to another country, implementation of Dayton Peace Agreement and problem-free maintenance of multiethnical structured model is dependent on success to be achieved in economy. Bosnians show that they have a good potential with their high education rate, hardworking and quick adaptation to changes, being easily motivated and ambition to establish business (Kondo, 91).

It is seen that the Balkan Peninsula had been invaded by Romans, Avars and Slavic tribes since the first age. Between 626 and 640, Serbian and Croatian tribes came to and settled in the northwest of the area. Croatians chose the Catholic church while Serbians entered into the Orthodox church. A community called Bosnians by the Ottoman, which stayed away from the both churches and believed in a sect called 'Bogomil' which rejected the trinity belief in Christianity, emerged in the $12^{\text {th }}$ century and had a monotheistic approach could easily adopt Islam when they encountered the Ottoman. Therefore, Bosnians have become a society with the same language as but a different religion from Serbians and Croatians. Upon Bosnian King Tomasevic ceased the tax (tribute) paid to the Ottoman, Mehmed the Conqueror conquered Bosnia in 1463 and Grand Vizier Mahmut Pasha conquered the Duchy of Herzegovina in 1467. Mehmed the Conqueror gave a big freedom to the local people, and even stated in a copy of an imperial order that they could fulfill the requirements of their religions freely, conveniently visit their houses of prayer, conduct all kind of religious ceremonies, live their customs and traditions freely, and their security of life and property was completely assured. Following the conquer of Bosnia, Bosnians collectively adopted Islam and protected the northwest border of the Ottoman on their own for many years (Kondo, 2003, 4-5).

Upon invasion of Dalmatia which would open the doors to the Balkans and the Mediterranean as the result of nationalist movements initiated by the French Revolution in the $17^{\text {th }}$ century, Christian minorities in Bosnia started revolts on the grounds that they were being oppressed. The Ottoman Empire tried to quell those revolts for many years but upon intervention by Russia, the Ottoman-Russian War 1877-78 broke out. As the result of the Ottoman-Russian war, Romania, Serbia and Montenegro gained their independence while Bulgaria announced its independency. The fight to clean the Balkans and Europe from the Ottoman as called the Historical East Policy by the Europeans was registered in the Berlin Conference 1878. Austria and Hungary invaded Bosnia-Herzegovina and made the annexation order in 1908. This order created a crisis between Austria-Hungary and Russia, Serbia and the Ottoman, and it was one of the reasons for breaking out of the World War I later. Upon dissolution of the Kingdom of Austria-Hungary at the end of the World War I, Bosnia-Herzegovina became a part of the Kingdom of Serbia-CroatiaSlovenia in 1918. After the World War II, it constituted the sixth republic in 1946 in addition to Serbia, Croatia, Montenegro, Macedonia and Slovenia comprising the Federal People's Republic of Yugoslavia. Muslims constituting the majority of the population in the said republic did not accept to be called as Serbians or Croatians and in 1971 Tito granted the Slav society which was Islamized in Bosnia-Herzegovina the nation status and the word Muslim written with ' $M$ ' became the name of a nation (Kondo, 2003, 5-7).

In old Yugoslavia the ethnical and religious structure was kept together for a long time but in upon death of Tito in 1980, ethnical movements started to be felt. While the office of presidency was required to be transferred to Croatia which was one of the six republics in 1991 as per the Yugoslavian constitution, Serbia did not allow exercise of this right to own 
Yugoslavia which was dissolving, on its own. This crisis resulted in announcement of independency by the other Federal Republic as well was also the reason for Serbians to attack the said republics in pursuit of the dream of "Great Serbia". Serbia attacked Croatia and Slovenia first, however, those conflicts came to an end upon intervention of Germany and the European Community. The general election held in the Republic of BosniaHerzegovina in 1990 was won by the Democratic Action Party led by Alija Izetbegovic and he was granted the presidency. Despite the boycott by the Serbians, the Republic of Bosnia-Herzegovina announced its independency in March 1992 as the result of a referendum. In this referendum, Muslims, Croatians and other minorities casted their vote in favor of independency and Serbians attacked Bosnia-Herzegovina with the federal army supporting Serbians and performed one of the biggest massacres of the $20^{\text {th }}$ century. Bosnians who fought against Serbians with Croatians in the beginning became alone upon Croatians taking the side of Serbians as the result of negotiations between the Serbian and Croatian presidents (Kondo, 2003, 7).

\section{RESEARCH METHOD}

Main material of the research is the natural and cultural resources of Bosnia-Herzegovina. Besides, main materials of the study include research and studies conducted on the subject matter, literature data and visual sources. The research is based on analysis of literature data and assessment of experiences and data obtained by direct observation. This study which is a document review defines what environmental and urban esthetics are, the effect of urban esthetics on tourism growth, and facilities of Bosnia-Herzegovina in terms of environmental and urban esthetics, and is intended to make these findings applicable in current use.

\section{TOURISM AREAS AND ESTHETIC OF BOSNIA-HERZEGOVINA}

For improvement of tourism in a country, it must have rich tourism resources. Availability of natural, cultural and historical resources is the prerequisite for healthy growth of tourism (Murphy et. al., 1999). There are four big touristic areas in Bosnia-Herzegovina. They include the central area (Sarajevo, Travnik, Foca, Srebrenik and Konjic touristic areas), Herseg area (Mostar, Trebinje, Capljina touristic areas), East Bosnia area (Tuzla and Doboj touristic areas), and West Bosnia area (livanj, Bihac and Banja Luka touristic areas) (Kondo, p. 133). Bosnia-Herzegovina is suitable for development of all kind of touristic activities with its natural resources including its geographical location, climatic diversity, rich flora and fauna, rich forests and thermal resources as well as its positive assets such as its cultural diversity and distribution of all these assets throughout the country. These activities can include Nature Tourism (Ecotourism), Sea Tourism, Mountain and Winter Tourism, Culture Tourism, Religious Tourism, Health Tourism, Thermal Tourism, Grief Tourism, Gastronomy Tourism, Educational Tourism and Congress Tourism etc. 


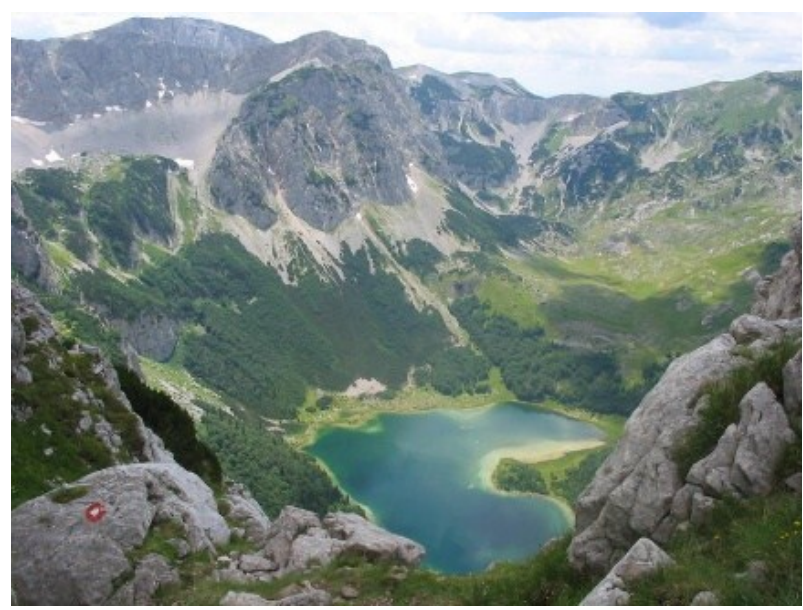

Fig. 1. Orlovacko lake

Nature Tourism (Ecotourism): Bosnia-Herzegovina has a significant ecotourism potential with its unique natural beauties created by its diverse ecosystem and many well-protected national and natural parks with intact natural beauties. Sutjeska National Park in the country is one of the first parks in Europe and places used for ecotourism purposes include Sutjeska National Park, Una National Park, Kozara National Park, HutovoBlato National Park, Bardaca Nature Park and Blidinje Nature Park. Bosnia-Herzegovina has touristic attractions for nature tourism with its climatic properties, superior landscape assets, traditional life style which is predominated by rural elements, and areas suitable for nature sports such as mountaineering, nature trips on horse, trekking, paragliding, flora/fauna examinations and jeep safari. In addition, rivers in the country create a suitable environment for rafting, canoeing and river skiing. In birdwatching, Mostar, Hutovo Blato, Zvornik, Srebrenica, Bijeljina and Brcko are transition locations where bird migrations can be observed especially in spring and autumn. The longest cave of Bosnia-Herzegovina which has a large number of mountains and the region is the Cave Vjetrenica while other important caves include caves of Bijambarska, Ledenica, Orlovaca, Djevojacka, Hrustovacka and Hukavica (BİH Tourism Sector, 2010,6). These areas have a great level of esthetic values which create positive emotions with its naturalness, integrity, unity, order, harmony, mystery and landscape beauty as well as its high level of recreational assets.

Sea Tourism: The city of Neum seated in the southwest of Bosnia-Herzegovina constitutes the country's door to the sea. Bosnia-Herzegovina hosts a lot of tourists with its coast on the Adriatic Sea of about $25 \mathrm{~km}$ length and 240 sunny days annually (BİH Tourism Sector, 2010). This area has a great esthetic value with its naturalness, landscape beauty, openness, perspective, order, and high recreational value. 


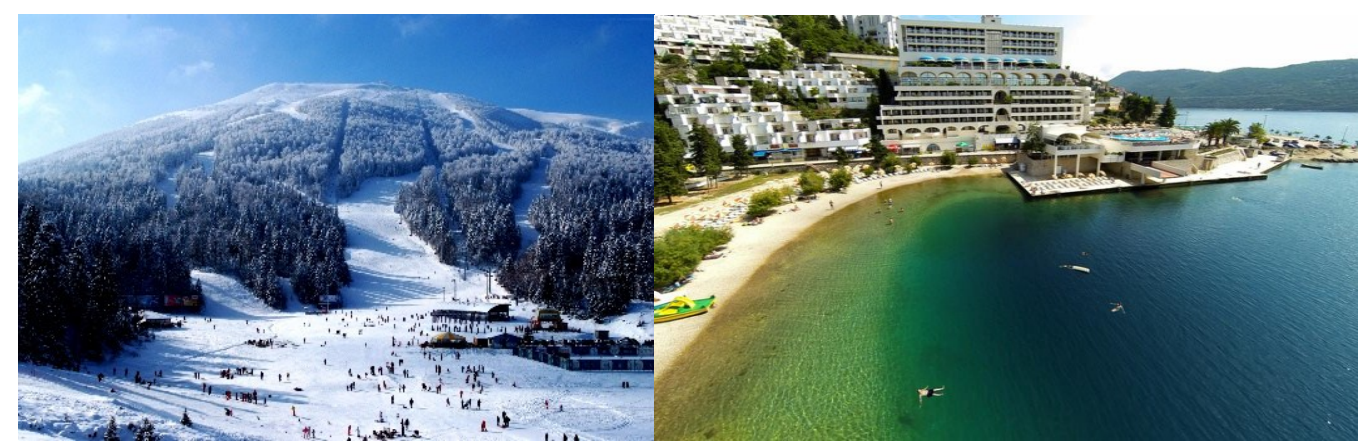

Fig. 2. Bjelašnica

Fig. 3. Neum

Mountain and Winter Tourism: Winter tourism has been an important tourism field for Bosnia-Herzegovina since old times. During winter months, high quality and continuous snowing provides suitable climatic conditions for winter tourism in the mountains of Bosnia-Herzegovina. Mountains Bjelasnika, Igman and Jahorina near Sarajevo which hosted the Winter Olympic Games in 1984 in Bosnia-Herzegovina are important winter sports centers and facilities which are about $30 \mathrm{~km}$ distant and have ski runs of $20 \mathrm{~km}$ length for Alpinism host tourists from different parts of Europe (BİH Tourism Sector, 2010). Mountains of Bosnia-Herzegovina which allow activities such as trips, research, trekking, climbing, picnic and winter sports have potential for hunting tourism and nature sports with its natural and wildlife diversity. These areas are tourism areas with high esthetical value with naturalness, integrity, unity, order, harmony, mystery, landscape beauty, high recreational value, diversity and landforms.

History and Culture Tourism: According to a study conducted by the World Tourism Organization, about $40 \%$ of touristic trips all over the world is based on culture tourism and its importance is increasing. Countries with a rich historical and cultural heritage can be significant attraction centers for tourists in near future. In this context, BosniaHerzegovina which hosted different cultures including Mediterranean, Roman, Ottoman and European cultures has a wide range of unique historical artifacts from the said cultures. Cultural heritage in Bosnia-Herzegovina has been protected from old monasteries and churches to bridges and mosques reflecting the Ottoman architecture despite the war. Some of the historical artifacts in Sarajevo include Kurşunlu Madrassa, Car Mosque, Bascarsia and the historical Fountain, Gazi Hüsrev Bey Mosque, Ali Pasha Mosque, Latin Bridge, SvriznaKuca, Orthodox Cathedral, Old Jewish Temple and Sarajevo Library and one of the most significant cultural values that Bosnia-Herzegovina has is the city of Mostar and Mostar Bridge. The bridge on River Neretva, which the city is named after was built by Architect Hayreddin who was a student of Sinan the Architect in 1566. Mostar Bridge was destroyed by artilleries shot during the war and rebuilt with support of Unesco and the World Bank. New Mostar Bridge opened in 2004 has been included in the World's Cultural Heritage list by Unesco in 2005. In addition to these two cities, there are countless historical artifacts and cultural values in the cities such as Banja Luka, Bihac, Pocitelj, Blagaj, Stolac, Bajca, Focinica, Bobovac, Kraljeva, Sutjeska, Vranduk, Prusac, Tesanj, Maglaj and Kradacac (BİH Tourism Sector, 2010). 


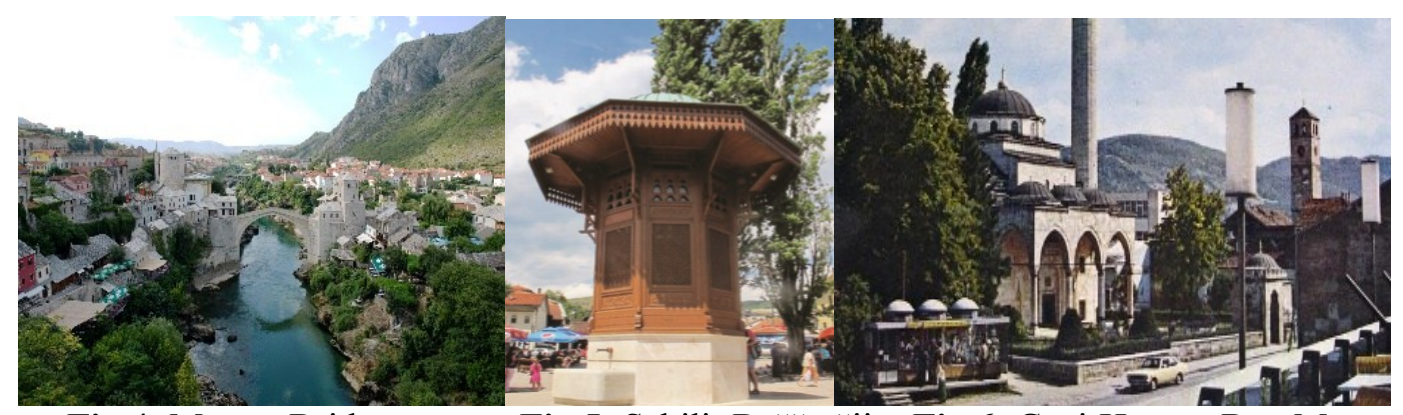

Fig.4. Mostar Bridge

Fig.5. Sebilj, Baččaršija Fig.6. Gazi Hüsrev Bey Mosque

In Islamic urban civilizations, public facilities such as fountain, mosque, school, market place and covered bazaars are located in the center with being surrounded by houses. For example, there is Bascarsia which has the fountain in its center (F10), mosque and covered bazaar in the center of Sarajevo. It is possible to see marks of the Ottoman and consequently the Turkish-Islamic culture in Bosnia-Herzegovina. There a wide range of examples to those marks, from courses of meal and grave types to architectural structure and handcrafts (F12, 13, 14 and 15). In addition, there is a great interest in celebrations and memorial ceremonies held in certain periods of the year in Bosnia-Herzegovina. Ayvaz Dede Festival which is held to pay immaterial debts to Ayvaz Dede on the last Sunday of June every year, Mostar Bridge jumping contest and Srebrenica memorial ceremonies are some of them. Esthetical properties of cities allowing History and Culture Tourism in Bosnia-Herzegovina generally include uniqueness, textural esthetic, determinacy, simplicity, availability of careful structural and decoration elements, organic order, use of natural building materials, reliability and perceptibility.

Religious Tourism: Religious elements in Bosnia-Herzegovina which is the meeting point of various civilizations and cultures play a significant role for religious tourism purposes. Bosnia-Herzegovina where Catholic and Orthodox Christianity, Judaism and Islam have co-existed throughout the history is called as Jerusalem of Europe. Serbians in the country are Orthodox and Croatians are Catholic while Bosnians are Muslim. Existence of different religions and ethnical origins in the country allow figures and sacred values belonging to the said religions to be visited by members of that religion. In addition to many mosques in different locations of the country remaining from the Ottoman period, there are Orthodox and Catholic Churches and Synagogues. Places and artifacts in Bosnia-Herzegovina considered holy by three different divine religions include Medjugorje (this small town where it is believed that Saint Maria was seen is visited by hundred thousands of Catholics), Sarajevo, Hüsrev Bey Mosque, Ali Pasha Mosque, Old Synagogue, Catholic Cathedral, Orthodox Cathedral, Kladanj, Kizın Cave, Travnik, New Mosque (Hasan Aga Mosque), Haji Ali Mosque, Banja Luka, Ferhadija Mosque (BİH Tourism Sector, 2010) etc. 


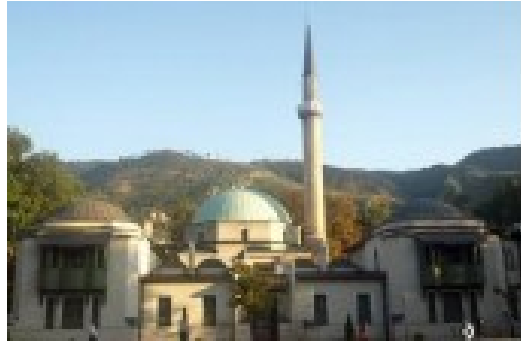

Fig. 7. Hünkar Mosque

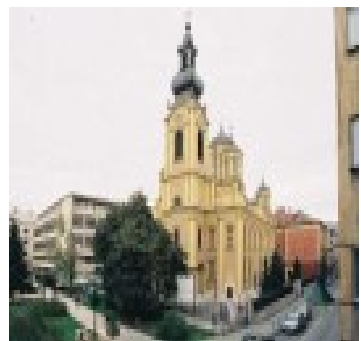

Fig. 9. Serbian Orthodox Church

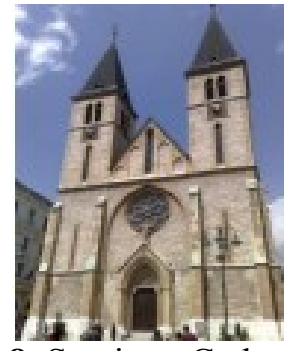

Fig. 8. Sarajevo Cathedral

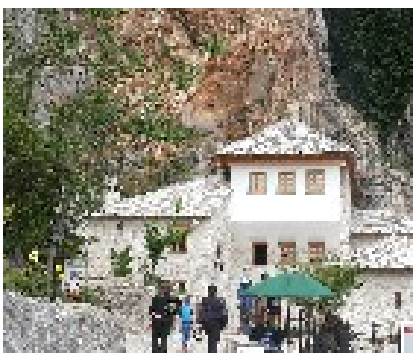

Fig. 10. Blagaj Tekke

In Bosnia-Herzegovina basic characteristic of big settlements is religious buildings which are the determinant element of the city silhouette. These buildings are structures with high esthetical value with their uniqueness, textural esthetic, simplicity, careful structuring and availability of decoration elements as well as use of natural building materials. The city silhouette has determinacy and perceptibility properties.

Health Tourism - Thermal Tourism: Bosnia-Herzegovina is among the first three countries in the Balkans and the top 10 in Europe with its geothermal resource diversity and potential. Thermal waters of Bosnia-Herzegovina have superior qualities than thermal waters in Europe with their flow rate and temperature as well as several physical and chemical properties. Thermal waters have natural outlets and high water yield, and high value of melt metals and are rich in sulfur, radon and salt. Cleanness and therapeutic properties of these waters attract many tourists to the country. SPA applications occurring as application of thermal waters using advanced physical therapy tools in body care and treatment comprise a tourism area with an increasing importance today. In BosniaHerzegovina highly advanced therapeutic spa centers have been established in recent years. Thermal centers in Bosnia-Herzegovina and their locations are as follows: Ilica, VilinaVilas (Visegrad), Sanskallidza (SanskiMost), Dvorovi (Bijeljina), Slatina and Laktasi (Banja Luka), Fojnica, BanjaVrucica (Teslic), Gata (Bihac), Guber (Srebrenica), Kiseljak (Sarajevo), Gradacac ve Mljecanica (Dubica) (BİH Tourism Sector, 2010). These areas have high esthetical value awakening positive emotions with their naturalness, integrity, unity, order, harmony, mystery, landscape beauty and high recreational value.

Grief Tourism: There are sad and painful happenings which even do not want to be remembered in the past of every society. Tourism activities carried out to remember these sad events, show respect to the casualties, or fulfill the haj duty is called grief tourism (Yirik and Seyitoğlu). Grief tourism is a type of heritage tourism which is also called as cultural heritage tourism. In this context, grief tourism is a type of tourism involving trip to such places where death events such as torture or genocide happened, and to monuments and museums built in the name of such events, and to places where painful events such as 
natural disasters happened. These areas for grief tourism make visitors feel the past events today with the grief they arouse and make them feel deep rooted and belonging to that place. Examples of grief tourism destinations include places where the World Wars I and II took place (Çanakkale etc.), Hiroshima, marks left by the war which took place in BosniaHerzegovina in 1992-95, genoice locations, mass graves and museums, flood disaster which took place in Soham Town of England (K1liç and Akyurt, 2011). In this context, the areas where the war took place in 1992 in Bosnia-Herzegovina, mass graves(F6), Srebrenica genocide locations, the Hope Tunnel (F8), the war museum, houses and streets where bullet marks can still be seen, Mostar Bridge, Pociteli and many other places can be seen and painful stories can be unfortunately witnessed. Unfortunately, in BosniaHerzegovina is one of the most important grief tourism centers which carries the marks of the war which took place when the technology and the civilization was well developed in the world.

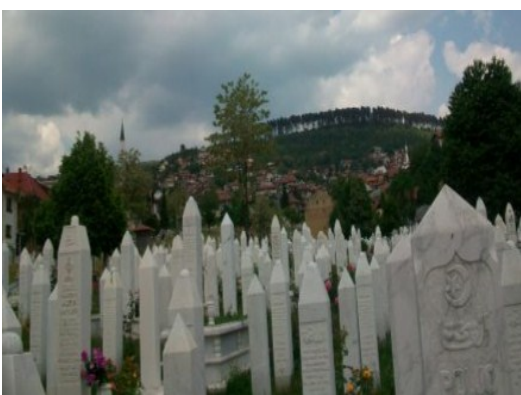

Fig.11. Graveyard in Sarajevo

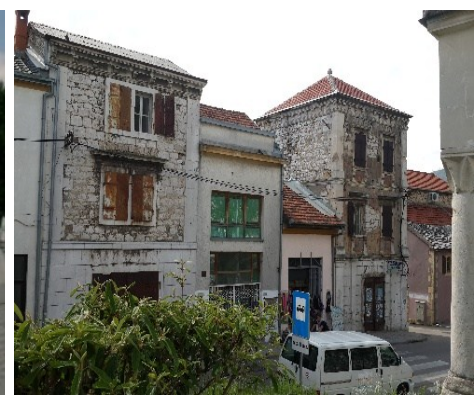

Fig.12. Mostar street view

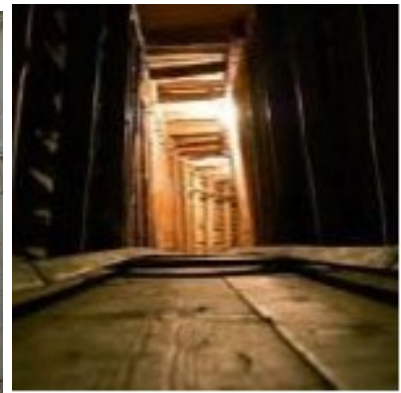

Fig.13. Tunnel of Hope

Gastronomy Tourism: Geography and geographical conditions are significant factors determining the food culture and products growing in a specific geography determine food types and eating habits. Food diversity in Bosnia-Herzegovina has been shaped both by geographical conditions and beliefs. In this context, in Bosnia which is highly rich in terms of Gastronomy Tourism, there are restaurants, hotels and souvenir shops with a wide range of options from Ottoman and Slavic cuisines to sheep and pork meat. Besides, BosniaHerzegovina is one of the preferred countries for educational and congress tourism purposes thanks to its natural and cultural diversity and being in the center of Europe.

\section{CONCLUSION AND SUGGESTIONS}

Esthetics which is an element affecting the experiential value of tourism facilities has an effect on customer perceptions. In esthetic experience, one is passively involved in a situation or environment. Esthetic value is the experiential value occurring as the result of consumption of products whose beauty is predominant, and is related to awareness of beauty which can be felt by senses (Oral and Çelik, 2013). When tourism in BosniaHerzegovina is considered from the perspective of esthetics, it has a strong tourism potential due to its perceptible visual or spatial harmony as well as many positive aspects in terms of spiritual esthetics and tourism in Bosnia-Herzegovina can grow with an esthetical planning approach.

Since Bosnia-Herzegovina had been controlled by the Ottoman for many years, there are also historical artifacts reflecting the Turkish-Islamic culture, and produced as the result of Christian and Judaist beliefs of Serbian and Croatian societies. As a reflection of this 
cultural and religious diversity, there is a rich cultural texture in handcrafts and gastronomy etc. in Bosnia. It is required to maintain this rich urban texture, protect urban esthetics and make urban planning being aware that it is a tourism city. Accordingly, this study is intended to draw attention to urban esthetics and tourism city esthetics in protection of natural and historical beauties and urban planning. When tourism in BosniaHerzegovina is evaluated in terms of urban esthetics, despite the tragic periods it went through, rapid restoration of damaged historical places, multi-cultural and multi-religious structure and synthesis of many civilizations or constituting the core with this property can attract tourists from many countries. Sad separations here in the past have turned into a tourism potential for the future. In Bosnia-Herzegovina where cultural and religious practices maintain their liveliness with all the dynamism, such practices can attract hundred thousands to itself, such as Ayvaz Dede Festival which carries all elements of spiritual esthetics as an extraordinary festival with its religious, cultural, identity, spatial and visual aspects.

Today when Bosnia-Herzegovina is evaluated in terms of tourism potential, it can be said that it relies on nature and culture tourism and has diversifiable tourism opportunities. The country has a significant potential for especially winter sports, spa tourism, and hunting and nature sports. Additionally, the country has a $25 \mathrm{~km}$ coast on the Adriatic Sea and hosted Bosnia-Herzegovina Winter Olympics in 1984 and has several facilities there. Thermal and mineral resources make great contributions to growth of tourism in the country as well. Educational, congress and gastronomy tourism are also important types of tourism. In the ecotourism field which is considered to be the fastest growing areas particularly in recent years, Bosnia-Herzegovina has also a significant potential with natural beauties it has (BİH Tourism Sector, 2010). In the cities of Bosnia-Herzegovina, characteristics and seasonal properties of its natural resources should be protected and improved.

In tourism industry, spatial beauty, historical buildings, environmental beauty and elements such as naturalness are intertwined with tourism, as well as esthetics involving their harmony. Since esthetics has an effect on tourism marketing, the conclusions reached from this study on Tourism in Bosnia-Herzegovina which emphasizes that natural and cultural values of the city should be protected and improved are as follows:

- During improvements and changes taking place and to take place in future in the cities of Bosnia-Herzegovina, cultural and physical values must be protected and not damaged or destroyed. Unique structure of these values must be protected as cultural heritage. Here, contemporary protection approaches must be considered, the principle of protection-use must be followed and ensuring sustainability must be the primary requirement.

- The greatest physical indicator of civilizations lies in cities. In the cities of BosniaHerzegovina where many different civilizations lived in, protection of material and immaterial values must be considered with urban dynamics.

- Constructions being made and to be made in natural areas of Bosnia-Herzegovina must be compatible with mass, position, density and structural properties as well as nature and integrity of respective area. It is extremely important to make these constructions in harmony with the nature in terms of their construction materials and structural condition and number of floors.

- In addition to tourism master plans to be individually prepared by the countries, a joint master plan must be issued by developing a tourism strategy primarily following international sustainable environmental protection policies for tourism master plans 
which are the interest of the entire ecosystem exceeding national boundaries to avoid any damage to natural ecosystems and basins. According to national ecological policies, tourism places must be planned as a master plan covering proper location selection decisions so as not to push the bearing capacity of the ecosystem or impair the natural resource and use balance (Gündüz, 2004, 60-64).

- In tourism planning to be made, professional disciplines including archeology, history, architecture, sociology, tourism, economy, urban planning, landscape architecture and forest engineering etc. must collaborate.

- The subject of urban esthetics which also constitutes resource for tourism is perceived at macro and micro level. Perception within the scope of urban appearance and city silhouette is at macro level while perception while living in that environment is at micro level. Micro perception is in color, form, measurement and textural details. Harmonic coexistence and well-integration of these textures is highly important for esthetics. In all kind of physical arrangements and urban design studies to be carried out especially in historical and natural environments in Bosnia-Herzegovina, unique properties should never be impaired. In urban planning of tourism destinations and decoration of tourism facilities, esthetical value aimed at micro perception should be featured in creation and presentation of products offered.

- Cities should have a certain esthetical attractiveness to be important tourism centers. In this context, esthetical feelings aroused by some structures in the cities of BosniaHerzegovina should be evaluated within the scope of their mass, façade and form properties as well as interior decorative properties.

- To increase tourism income to Bosnia-Herzegovina from these cultural and religious visits whose importance has been increasing, infrastructural and superstructure deficiencies of significant centers of three divine religions including Islam, Christianity and Judaism reaching to the present day (Sarajevo, Medjugorje, Prusac, Travnik) must be removed and it is requiredto increase number of visitors through publicity activities.

In conclusion, Bosnia-Herzegovina must be certainly considered in terms of culture tourism with its centuries-old historical artifacts, gastronomy, maintained traditions, and handcrafts, religious tourism with pieces from different religions, and grief tourism potential with its locations which carry the marks of the war. In addition to these, its nature tourism potential must also be considered with its emerald green rivers, the Alps where Olympic ski centers are constructed, deep canyons and the Adriatic coast. However, during the economic development needed to bind up the war wounds of the country, extreme attention must be paid to keep this natural wonder city and its surroundings from industry and it is required to plan tourism marketing of the city with sustainable tourism approach. Instead of an esthetic based on consumption of nature in cities, an esthetical approach which targets to regain the nature and esthetical values of the historical and cultural background and seek to incorporate the said into life.

\section{REFERENCES}

- Booth, N.K..(1990). Basic Elements of Landscape Architectural Design, Waveland Press Inc., USA.

- Bosna Hersek Sektör Raporları Turizm Sektörü, Türkiye Kalkınma Bankası A.Ş. Ekonomik ve Sosyal Araştırmalar Müdürlüğü, Ocak 2010 Ankara.

- Bozkurt, N. (2000). Sanat ve Estetik Kuramları, Bursa, Asa Kitabevi, Özal Matbaası. 
- Clay, G.R., Daniel T.C.(2000).Scenic Landscape Assesssment: The Effects of Land Management Jurisdiction on Public Perception of Scenic Beauty Landscape and Urban Planning, 49, 1-13.

- Çakcı, I. (2007). Peyzaj Planlama Çalışmalarında Görsel Peyzaj Değerlendirmesine Yönelik Bir Yöntem Çalışması, Peyzaj Mimarlığı Anabilim Dalı, AnkaraÜniversitesi, Ankara.

- Daniel, T.C. (2001).Whither Scenic Beauty? Visual Landscape Quality Assessment in The 21st Century. Landscapeand Urban Planning, Volume 54, Issues 1-4, 267-281.

- $\quad$ Erdoğan, E. (2006). Çevre ve Kent Estetiği. ZKÜ Bartın Orman Fakültesi Dergisi, C:8, S:9.

- $\quad$ Ergün, Ö.(2005). Effects of Observation Plan and Precision, Survey Review, Vol.38No.298, 331-341.

- Erzen, J. (2006).Çevre Estetiği, Ankara, ODTÜ Geliştirme Vakfı Yayıncılık ve İletişim A.Ş. Yayınları.

- $\quad$ Erzen, J.(2011). Kent Estetiği. Dosya 23. TMMOB Mimarlar Odası yayını. ISSN 1309-0704. 16.

- $\quad$ Fuante de Val, G.,Atauri A.J., Lucio J.V. (2006). Relationship between landscape visual attributes and spatial patternindices: A test study in Mediterranean- climate landscapes. Landscape and Planning, V:77, I:4, 393-407.

- Gedikli, B. (2012). Sürdürülebilir Kentsel Gelişim, June, 2012.

- Gündüz, F. (2004). Çevre ve Turizmin Sürdürülebilirliği, TMMOB Şehir Plancıları Odası Yayınları: Planlama, 2004/1, Issn 1300-7319, No:27, S.58-67.

- İzgi, U. (1999). Mimarlıkta Süreç, Kavramlar-İlişkiler, İstanbul, Yapı Endüstri Merkezi Yayınları, Yem Yayınevi.

- Kılıç B., Akyurt H. (2011). Destinasyon İmajı Oluşturmada Hüzün Turizmi: Afyonkarahisar ve Başkomutan Tarihi Milli Parkı, Gaziantep Üniversitesi Sosyal Bilimler Dergisi, 10(1): 209-232.

- Kırayoğlu, M. (2012). Balkan Coğrafyası, Balkanlar'ın dört ülkesinde TKB incelemesi, Balkanlar'a Koruma Yolculuğu, TKB geçmişten Geleceğe E-Yerel Kimlik Dergisi, No:31, 4151 .

- Koçan, N. (2012). Ömer Lütfü Çorbacı, Tarihi Çevreleri Koruma Sürecinde Yeni Yaklaşımlar: Kongre Turizmi, Safranbolu Çarşı Örneğinde Bir Araştırma, Mehmet Akif Ersoy Üniversitesi Fen Bilimleri Enstitüsü Dergisi 3(2): 31-36.

- Kondo, S. (2003). Bosna-Hersek Coğrafyas1, Ankara Üniversitesi Sosyal Bilimler Enstitüsü Coğrafya (Türkiye Coğrafyası) Anabilim Dalı Bosna-Hersek Coğrafyası Yüksek Lisans Tezi, Ankara, 2003.

- Kurtuldu, H.S., Yıldız, S. Çilingir, Z. (2010). Web Sitelerinin Pazarlanmasında Estetik Özelliklerin Rolü: Online Gazeteler Üzerinde Bir Araştırma, Dumlupınar Üniversitesi Sosyal Bilimler Dergisi, S:26.

- $\quad$ Kuter, N.(2007). Çankırı Kenti ve Çevresinin Turizm Açısından Değerlendirilmesi, ZKÜ Bartın Orman Fakültesi Dergisi, Volume:9, No:11.

- Mazı, F. (2009). Tarihi Çevrenin Korunmasında Sosyo-Ekonomik Faktörlerin Etkisi, Mevzuat Dergisi, Y1l:12, say1:138, Haziran 2009, ISSN 1306-0767.

- Ode, A.K.,Fry G.L.A.(2002). Visual Aspects in Urban Woodland Management. Urban Forestry and Urban Greening, 1, 15-24.

- Oral, S. Çelik,A. (2013). Türkiye'yi Ziyaret Eden Turistlerin Estetik Deneyimleri Üzerine Bir Araştırma, İsarder (İşletme Araştırmaları Dergisi), 5/4, 170-190.

- Özder A. (2012). Bosna-Hersek Cumhuriyeti’nde Coğrafyanın Halk Kültürüne Etkisi, Marmara Coğrafya Dergisi No: 25, January, S. 213-237.

- T.C. Başbakanlık Devlet Arşivleri Genel Müdürlüğü Osmanlı Arşivi Daire Başkanlığı Yayın No:7, Bosna-Hersek ile İlgili Arşiv Belgeleri (1516-1919), Ankara-1992.

- Tahvanainen, L.,Ihalainen M., Hietala-Koivu R., Kolehmainen O., Tyrvainen L., Nousiainen I., Helenius J. (2002). Measures of the EU Agri-Environmental Protection Scheme (GAEPS) and 
their impacts on the visual acceptability of Finnish agricultural landscapes. Journal of Environmental Management 66, 213-227.

- $\quad$ http://utek.ibu.edu.ba/assets/utek/userfiles/documents/Bosna-Hersek-Gezi-Rehberi.pdf), 10.08 .2015

- $\quad$ http://www.haber7.com/balkanlar/haber/829802-turkiyeden-bosna-herseke-turizm-destegi, 10.08 .2015

- http://docplayer.biz.tr/443146-Tursab-turkiye-kongre-turizmi-raporu-2013-turkiye-de-3-milyardolarlik-kongre.html, 10.08.2015

- $\quad$ https://www.academia.edu/12521734/H\%C3\%9CZ\%C3\%9CN TUR\%C4\%B0ZM\%C4\%B0 VE_MABETLE $\%$ C5\%9EME_S\%C3\%9CREC $\%$ C4\%B0_KAPSAMINDA_SARIKAMI $\%$ C $5 \%$ $\underline{\text { 9E, } 10.08 .2015}$

- "Estetiğin Konusu”, http://www.egitim.aku.edu.tr, Mustafa Ergün, 10.08.2015

- $\quad$ http://www.cografya.gen.tr/, 16.08.2015. 